\title{
Investigation of Under-Utilised Wood Species for Potential Utilisations in Taraba State, Nigeria
}

\author{
Josiah T. B. Riki, Abel A. Maiguru, Sabo S. Zaku, and Bwaseh J. B. Auta
}

\section{ABSTRACT}

Under-utilsed wood species from Taraba State were studied to generate information for identification purposes and facilitate the introduction of these species into the wood working industry by assigning or widening the potential uses of these species to serve as alternative economic species. They are wood species that constitutes the bulk of wood that finds no economic use and their current commercial demand is below their forest production potentials. This study examines under-utilised wood species in the three (3) ecological zones (Northern guinea savanna, Mountain Grassland/Forest Vegetation and Southern guinea savanna) in Taraba State with a view to identifying their utilisation potentials. A total of 60 respondents comprising of wood dealers, furniture makers and chainsaw operator were selected with 20 questionnaires per region using convenient and systematic random sampling techniques. Researcher made closed ended questionnaires as instrument of data collection. Descriptive statistical tools such as frequency, percentage and charts were used, and data collected were analysed using Startsoft Statistica 12.5. Results showed that males $(85 \%)$ had the highest percentage than the females $(15 \%)$. Majority were between age brackets of 21-30 which constitute $46.67 \%$. Considerable number of them were married and not well educated. The study also, revealed Fifteen (15) of the most common under-utilised and endangered wood species with six (6) currently traded species were revealed. Wood demand, durability and availability are the major reasons for choice of species traded while, over-exploitation and seasonality are the main reasons for fluctuations in species availability for trade. Assessment of deforestation in the study area was high, which shows decrease in availability of woody plant species. The produced compendium of some under-utilised wood species from Taraba State, should be distributed widely so that producers, users, and marketers of wood products are aware of the promising species as an alternative to economic species for sustainability.

Keywords: Sustainability, Under-Utilised, Utilisation, Wood.
Submitted : August 27, 2021

Published : October 12, 2021

ISSN: $2684-1827$

DOI: $10.24018 /$ ejfood.2021.3.5.366

\section{J. T. B Riki*}

Department of Forestry and Wildlife Management, Faculty of Agriculture and Life Sciences, Federal University Wukari, P.M.B 1020, Taraba State, Nigeria.

(e-mail: rikijosiah@gmail.com)

A. A. Maiguru

Department of Forestry and Wildlife Management, Faculty of Agriculture and Life Sciences, Federal University Wukari, P.M.B 1020, Taraba State, Nigeria.

S. S. Zaku

Department of Forestry and Wildlife Management, Faculty of Agriculture and Life Sciences, Federal University Wukari, P.M.B 1020, Taraba State, Nigeria.

(e-mail: author@nrim.go.jp)

B. J. B. Auta

Department of Forestry and Wildlife Management, Faculty of Agriculture and Life Sciences, Federal University Wukari, P.M.B 1020, Taraba State, Nigeria.

*Corresponding Author

\section{INTRODUCTION}

Man has been making use of wood for diverse purposes from time immemorial. It is known that the earliest humans used wood to make shelters, cook food, construct tools, and make weapons. Wood is a hard, fibrous tissue found in many trees used for fuelwood, timber, poles, plywood, particle board, fibreboard production, carving, pulp and paper production and other industrial raw materials. It's a complex material attractive to many users because of its versatility [1].

Wood, being a construction material, has been used for different purposes, including structural and ornamental purposes. It is used throughout the world for many tasks, from simple structural application to highly finished and ornate decoration and it is the dominant industrial material in Nigeria [2], [3]. There are approximately 200,000 hardwood species and 1000 softwood species in Nigeria, of the total number; only 2,300 tree species are commercially important [4]. In building and furniture industries, various species of timber are used for different purposes. The choice of wood species used varies, due to different features and characteristics of the wood, some of these features are wood strength, natural durability, colour (appearance), ease of machine and workability, cost, contraction, hardness, and availability [3].

The shortage in supply of wood from forest to meet the high market demand with preference is due to overexploitation of the sought after known and marketable wood species. This is often attributed to global socio-economic realities such as increase population and advancement in technology [5]. The recent discovery and exploitation of Pterocarpus erinaceous (Rosewood/Madrid wood) and other economic species in the sub humid Savanna lands of Taraba state has generated a lot of concern. The high rate of harvesting of forest tree species and the large traffic flow of this wood timber across the State is a source of concern because of its likely consequence on the environment. This has also led to extremely serious harmful consequences for the species of tree in the environment, most especially where it is grown and pressure from increasing human populations [6]. To reduce pressure on widely used species and to induct the alternative supply of wood resources, utilisation of native 
under-utilised wood species will be considered as essential task.

Taraba State has a vast array of diverse indigenous biodiversity including woody species hence the nickname 'Natures gift to the nation'. The State is made up of three major ecological zones that are typified by the co-existence of woody plants [7], with relative proportions of being influenced predominantly by water availability, fire, nutrients, herbivores, and people [8].

The under-utilised or commercially least-concerned wood species are generally termed as lesser-known species (LKS) or lesser used species (LUS) due to insufficient information about their wood properties and probable end-uses [9]. According to Barany et al. [10], LUS constitute the bulk of wood with very little economic use. But inherent production potentials of LUS are higher than their current commercial demand [11]. This study will therefore investigate underutilised wood species as an alternative to the economical wood species in Taraba State, Nigeria.

\section{MATERIALS AND METHODS}

\section{A. Study Area}

The study was carried out in Taraba State which lies roughly between latitude 630" and 936" north and longitude 910" and 50" east. It is bounded on the North by Bauchi State and Gombe State on the North-east. It is also bounded by Adamawa State on the east and Plateau State on the Northwest. The State is further bounded to the west by both Nasarawa and Benue States, while it shares an international boundary with the Republic of Cameroon to the South and South-east [12]. Rainfall distribution and topography are the most important factors influencing the pattern of vegetation in Taraba State. The vegetation may be classified into three broad types: The Northern Guinea, the Southern Guinea and the Mountain Grassland and Forest Vegetation [13]. The boundary between the Northern Guinea and Southern corresponds fairly closely with the $1400 \mathrm{~mm}$ mean annual rainfall isohyet, while the mountain forest and grassland vegetation occur mainly on the Mambilla plateau. Most of the lowland areas are made up of ferruginous tropical soils which developed on crystalline acid rocks and sandy parent materials. The upland areas, especially the Mambilla plateau, are covered by humic ferrosols and lithosols which are highly weathered and markedly literalized, due to leaching [12]. Taraba has sixteen (16) Local Government Areas with Jalingo as the State headquarters.

\section{B. Sampling Procedure and Sample Size}

Considering the number of the research population and due to the fact that the respondents especially the local residents might not be found assembled at one place for the questionnaires and interview guide to be administered, the simple random sampling was used to select the respondents in the study area because it will give every respondent equal opportunity to participate in the study without any bias. A total of Sixty (60) closed-ended structured questionnaires were administered to elicit information in the study area. Twenty (20) in Ado-Kola (Northern Guinea Savanna), Twenty (20) in Sarduna (Mountain Grassland and Forest Vegetation) and Twenty (20) in Kurmi (Southern guinea Savanna) Local Government Areas of Taraba State.

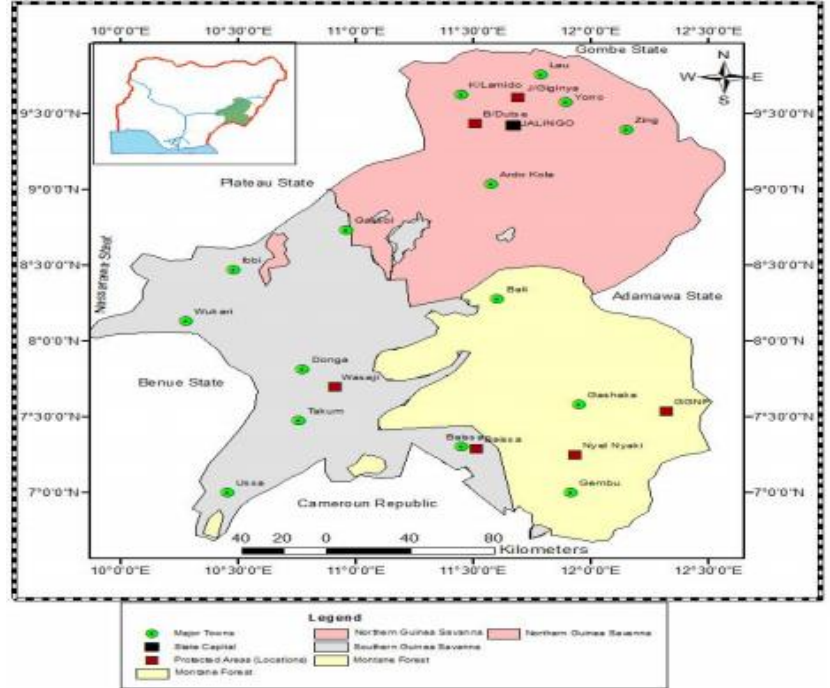

Fig. 1. Map of the Study Area. Source: [14].

\section{Sources of Data Collection}

The Primary Data collected directly from the field by the researchers through Focused Group Discussion (FGD), structured questionnaire and field observations were used for the study. Three categories of data sources deem relevant to the study which are: Wood vendors or sellers, wood users within the community, and wood harvesters or chainsaw operators.

\section{Data Analysis}

Data collected from the administered questionnaire were processed using Startsoft Statistica 12.5. Descriptive statistical tools such as frequency, percentage and charts were used to determine the factors that influences the choice of wood species.

\section{RESULTS AND DISCUSSIONS}

\section{A. Socio-economic Characteristics of Respondents}

Results in Table I a shows gender of the wood vendors in the study area, they were predominantly male with the highest percentage of $58 \%$ while $15 \%$ was recorded for women. The reason is probably due to the nature of the job, it is extremely physical and labour intensive and above all risky, dirty, and delicate thereby, limiting the involvement of women. Forest operation which is an aspect of forestry industry requires physical strength to move sawn timber for processing. In line with the traditional Africa setting, men are mostly required to carry out energy sapping activities while the women are majorly saddled with upbringing of children, household care and petty trading to augment family income [15], [16]. The result of this work is in agreement with the work of Ogunjobi et al. [17]. The result also, agrees with the findings of Manfre and Rubin [18], they reported that men contribute more to household income than women because their forest activities are income generating whereas women are more involved in subsistence activities. The result equally, agrees with the findings of ILO [19] who reported that in the United States, only $6.3 \%$ of women worked in male-dominated occupations in 2016 and only $3.2 \%$ are involve in logging.

Age group between 21-30 years had the highest per cent of 46.67 and the least was found between age group of 15-10 
with $11.66 \%$, meaning the youths are the ones who are actively involved in the business of wood vendors in Taraba State. The reason may be that youths areagile/active; wood business involves much energy, strength, and endurance. This result agrees with the findings of David [20] whose report confirmed that logging business is mostly done by agile youths who should be in school, but by reason of poverty are forced to indulge in this business. The observed result in this study is also in consonance with the work of Yani et al. [6] who previously, reported more youths in wood business in Taraba State within almost same age group and that of Awe et al. [3]. By virtue of strength attributable to the age class and experience garnered, the wood industry will thrive better if they have better equipment and financial support.

The married were more involved in this wood business than singles and others as they have the highest percentage of $53.34 \%$. The reason may be linked to responsibility issue; married people are more conscious of the needs of their family therefore more were involved in the wood activities. This result corresponds with the findings of Yani et al. [6] and Omolehin et al. [21]; they reported that married farmers are more conscious of the need to get better yields so that they could meet their family food needs.

Results from educational level of respondents shows those with secondary $(43.33 \%)$ and primary education $(30 \%)$ had the highest level of education in the study area. Those whose responsibility is cutting, rolling logs down the mountain top, loading and offloading were mostly those having no formal education, primary education, and secondary education, and from observation they embarked on it basically because of the monetary aspect; they have no idea about the effects and dangers of logging and deforestation to the environment. Though the activities involved does not require that they acquire higher education, good educational level is important for skill and technology acquisition as well as capacity building which would reduce accident and enhance proper documentation towards profit making. Education has been known to be the gateway to better and efficient output and service delivery. The result agrees with the results of Ogunjobi et al. [17] who reported more respondents involved in wood business with secondary and primary educations. The research findings point out that most of the respondents involved in logging have had some level of formal education which if properly taught could embrace afforestation practice and selective fellings during logging activities for sustainability.

Meanwhile, in terms of field of specialization in wood business in the study area, $53.33 \%$ are wood dealers, followed by Furniture makers/saw millers with $23.33 \%$. This simply means most of the people involved in wood business have no technical knowledge of wood operation, but they are after buying the woods, no wonder they are less concern with the mode of forest operations which has affected the environment as they are after the profits they will make.

Similarly, Table I shows results of years in wood business where 38.33 and $31.67 \%$ of respondents between 1-10 and 11-20 years are higher. This is a clear indication that we have more people joining the wood business in the last 10-20 years in Taraba State and this could be as a result of the huge amount of money been realised in selling the wood business in detriment of their environment. Only $11.67 \%$ have proper experiences in the business in the study area. Higher experience and length of training mostly results in better skills on the job and better chances of higher returns on investment [16], [22].

Respondent's ethnicity revealed in Table I also, shows that the major tribe involved in the wood activities that is cutting, rolling logs down the mountain top, loading, and offloading of wood species are Hausas/Fulanis and Junkuns with 38.33 and $31.67 \%$ respectively. This probably because Hausas/Fulanis and the Junkuns are the majority in the wood business when compared to other tribes. They are the main indigenes of Sarduna and Kurmi Local Government Area which have the highest activities of forest operations with different Chinses companies situated in their lands, and they also lay claims to most of these forest areas as natures gift to their parents of which they are heirs and more over they knew the terrain of the forest better than anyone coming into the area. The result agrees with findings of Harper [23] and Yani et al. [6] who says that the most important ethnic groups in the Local Government area are the Hausa/Fulanis in ArdoKola and Sarduna while Jukun (Ichen mostly) in Kurmi Local Government Area of Taraba State. Similarly, all the Local Government Areas selected for the study (Ardo-Kola, Kurmi and Sarduna) actively participated in the study with $33.3 \%$ each. This is an indication that there was cooperation between the researcher and the respondents in the study area.

TABLE 1: SOCIO-ECONOMIC CHARACTERISTICS OF WOOD SELLERS

\begin{tabular}{|c|c|c|}
\hline \multicolumn{3}{|c|}{$(\mathrm{N}=60)$} \\
\hline Variable & Frequency & Percentage $(\%)$ \\
\hline \multicolumn{3}{|l|}{ Gender } \\
\hline Male & 51 & 85 \\
\hline Female & 9 & 15 \\
\hline \multicolumn{3}{|l|}{ Age Group } \\
\hline $15-20$ & 7 & 11.66 \\
\hline $21-30$ & 28 & 46.67 \\
\hline 41 and above & 25 & 41.67 \\
\hline \multicolumn{3}{|l|}{ Marital Status } \\
\hline Single & 17 & 28.33 \\
\hline Married & 32 & 53.34 \\
\hline Others & 11 & 18.33 \\
\hline \multicolumn{3}{|l|}{ Level of Education } \\
\hline Primary & 18 & 30.00 \\
\hline Secondary & 26 & 43.33 \\
\hline Tertiary & 9 & 15.00 \\
\hline Non formal education & 7 & 11.67 \\
\hline \multicolumn{3}{|c|}{$\begin{array}{l}\text { Field of Specialisation in Wood } \\
\text { business }\end{array}$} \\
\hline Chainsaw operator & 9 & 15.00 \\
\hline Wood dealer & 32 & 53.33 \\
\hline $\begin{array}{l}\text { Furniture makers/saw } \\
\text { millers }\end{array}$ & 14 & 23.33 \\
\hline Others & 5 & 8.34 \\
\hline \multicolumn{3}{|l|}{ Years in Wood Business } \\
\hline $1-10$ & 23 & 38.33 \\
\hline $11-20$ & 19 & 31.67 \\
\hline $21-30$ & 11 & 18.33 \\
\hline 31 and above & 7 & 11.67 \\
\hline \multicolumn{3}{|l|}{ Tribe } \\
\hline Jukun & 23 & 31.67 \\
\hline Hausa/Fulani & 19 & 38.33 \\
\hline Igbo & 5 & 8.33 \\
\hline Yoruba & 9 & 15.00 \\
\hline Chinese & 4 & 6.67 \\
\hline \multicolumn{3}{|l|}{ Local Government } \\
\hline Ardo-Kola & 20 & 33.33 \\
\hline Kurmi & 20 & 33.33 \\
\hline Sarduna & 20 & 33.33 \\
\hline Total & 60 & 100 \\
\hline
\end{tabular}

Source: Field Data Analysis, 2021.

\section{B. Assessment of Under-utilised Species Status in the Study Area}

Results from Table II, however revealed that $76.67 \%$ of the respondents in the study knew the concept of under-utilised 
wood species. $65.00 \%$ said they do not think the underutilised Species can serve same purpose as the economical species used for roofing, furniture, decoration, carving and construction purposes. $31.67 \%$ believed that the underutilised wood species are not strong as $55.00 \%$ believed it was a general norm in the region and $28.33 \%$ used them for fuelwood. The rising demand for under-utilised species was a result of increase in population $(26.67 \%)$, scarcity of economic species $(18.33 \%)$, elastic properties of the wood species $(3.33 \%)$ among other reasons. Strength properties such as physical and mechanical properties of wood species are technical information that required scientific analysis to ascertain them not by assumption as believed by the respondents in the study area. Knowledge of the strength properties of any wood will definitely determine its end uses whether for construction purposes or for paper production. Wood species for pulp and paper production requires low specific gravity so as to facilitate the impregnation and penetration with cooking liquor [24].

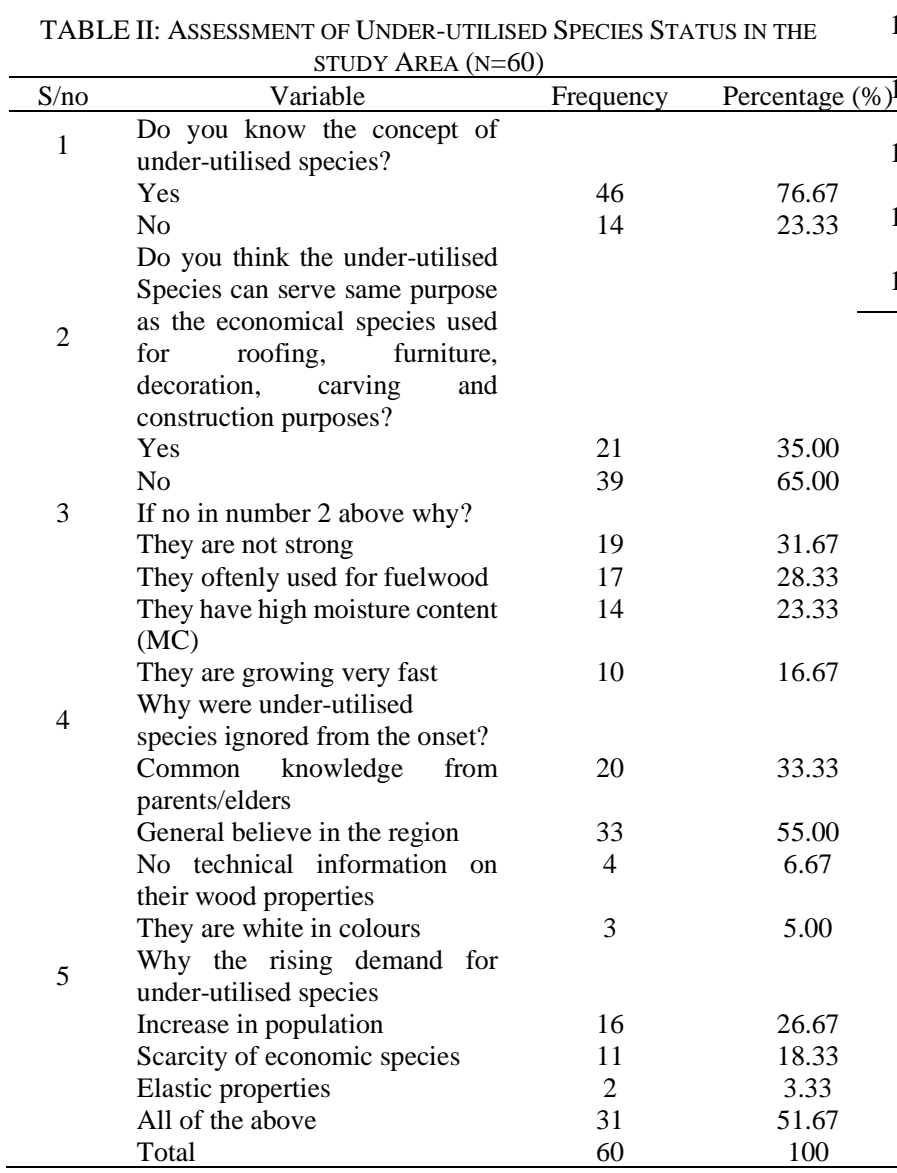

Source: Field Data Analysis, 2021.

The results revealed that under-utilised wood species were not new to them but have decided to neglect them probably due to lack of technical information about their uses. One major reason why many of these tree species have hitherto remained unpopular as timber species is the lack of sufficient information about their properties. In popularizing a species or a group of wood, the properties have to be known as they serve as criteria for their selection for a particular application [25]. Wood structures that are well constructed without adequate knowledge of their strength properties used to perform poorly when compared with engineered structures [26]. The success of under-utilised wood species in the market requires technical information that relates to utilization about the species [27].

TABLE III: FIFTEEN (15) MOST COMMON UNDER-UTILISED SPECIES IN TARABA STATE

\begin{tabular}{|c|c|c|c|c|}
\hline $\mathrm{S} / \mathrm{N}$ & Scientific Name & Family & Local Name & Hausa name \\
\hline 1 & $\begin{array}{l}\text { Anogeissus } \\
\text { leiocarpus }\end{array}$ & Combretaceae & Africa birch & Marke \\
\hline 2 & $\begin{array}{l}\text { Prosopis } \\
\text { Africana }\end{array}$ & Fabaceae & $\begin{array}{l}\text { Africa } \\
\text { mesquite }\end{array}$ & Gele \\
\hline 3 & Daniellia oliveri & Fabaceae & Africa copaiba & Maje \\
\hline 4 & $\begin{array}{l}\text { Terminalia } \\
\text { glaucescense }\end{array}$ & Combretaceae & Senegal & Baushe \\
\hline 5 & $\begin{array}{l}\text { Tamaridus } \\
\text { indica }\end{array}$ & Fabaceae & Tamarind & Busai \\
\hline 6 & $\begin{array}{l}\text { Parkia } \\
\text { biglobosa }\end{array}$ & Fabaceae & $\begin{array}{c}\text { Africa locust } \\
\text { beans }\end{array}$ & Doruwa \\
\hline 7 & $\begin{array}{l}\text { Vitellaria } \\
\text { paradoxa }\end{array}$ & Sapotaceae & $\begin{array}{c}\text { Shea butter } \\
\text { tree }\end{array}$ & Kadanya \\
\hline 8 & $\begin{array}{l}\text { Deinbolia } \\
\text { pinnata }\end{array}$ & Sapindaceace & Water willow & \\
\hline 9 & $\begin{array}{l}\text { Sterculia } \\
\text { setijera }\end{array}$ & Sterculiaceae & Gum tree & Kukkuki \\
\hline 10 & $\begin{array}{l}\text { Balanite } \\
\text { eagyptiaca }\end{array}$ & Zygophyllaceae & Desert date & $\begin{array}{c}\text { Aduwa/Chba } \\
\text { ro }\end{array}$ \\
\hline 11 & $\begin{array}{l}\text { Schefflera } \\
\text { abyssinica }\end{array}$ & Araliaceae & Harms & \\
\hline b) & $\begin{array}{l}\text { Uapaca } \\
\text { guineensis }\end{array}$ & Euphorbiaceae & Sugar plum & $\begin{array}{l}\text { Wawan } \\
\text { kurmii }\end{array}$ \\
\hline 13 & $\begin{array}{l}\text { Strychonos } \\
\text { spinosa }\end{array}$ & Loganiaceae & $\begin{array}{l}\text { Elephant/Kaffi } \\
\text { r orange tree }\end{array}$ & \\
\hline 14 & $\begin{array}{l}\text { Pleiocarpa } \\
\text { pycnantha }\end{array}$ & Apocynaceae & Pleiocarpa & \\
\hline 15 & $\begin{array}{l}\text { Garcinia } \\
\text { smithmanii }\end{array}$ & Clusiaceae & Satree & Gworo \\
\hline
\end{tabular}

\section{Endangered Timber Species in Taraba State}

From this study, it has been discovered that preference for certain wood species in the market due to their high quality, strength and durability has resulted in the over-exploitation of such species. Hence, such species are now scarce and not readily available in the market. These species are regarded as endangered species because of the sharp decline in their availability in the market. These endangered species in Taraba State are listed in Table IV. This also corroborates the work of Bunde [14] that stated almost same species in Taraba State. Similarly, these results corroborate with the work of Famuyide et al. [28] and Awe et al. [3] who earlier mentioned some the endangered species from this study in Oyo and Kogi, respectively.

\begin{tabular}{ccc}
\multicolumn{3}{c}{ TABLE IV: ENDANGERED TIMBER SPECIES IN TARABA STATE } \\
\hline S/no & Scientific Name & Local Name \\
\hline 1 & Milicia excels & Iroko \\
2 & Ptericarpus erinaceus & Rosewood \\
3 & Afzelia Africana & Apa \\
4 & Khaya senegalensis & Mahogany \\
5 & Nauclea dideriichii & Opepe/Tafaashiiya \\
6 & Triplochiton scleroxylon & Obeche \\
7 & Terminalia superba & Africa limba/Afara \\
8 & syngonium Erythrophyllum & Arrow head \\
9 & Anogeissus leiocarpus & Africa birch/Bambara \\
10 & Tectona grandis & Teak \\
11 & Gmelina arborea & Gmelina \\
12 & Cordia millenni & Omo \\
13 & Allophylus Africana & Allophylus \\
14 & Chrysophyllum delevayi & Star Apple \\
15 & Mitragynia ciliate & Abura \\
\hline Source Field Data Analysis, 2021 &
\end{tabular}

\section{Wood Species Currently Traded in Taraba State}

Table V shows some of the wood species that are currently traded in Taraba State which include: Ptericarpus erinaceus (Madridwood), Afzelia Africana (Apa), Albizia gummifera 
(Albizia), Syngonium erythrophyllum (Arrow head), Anogeissus leiocarpus (Bambara) and Gmelina arborea (Gmelina). This is in consonance with the work of Bunde [14], who has earlier mentioned some of the species in his studies in Taraba State.

\begin{tabular}{ccc} 
TABLE V: TIMBER SPECIES CURRENTLY TRADED IN TARABA STATE \\
\hline S/no & Scientific Name & Local Name \\
\hline 1 & Ptericarpus & Rosewood/Madrid wood \\
2 & erinaceus & Afzelia Africana \\
3 & Albizia gummifera & Albizia \\
4 & Syngonium & Arrow head \\
& erythrophyllum & Anogeissus \\
5 & leiocarpus & Africa birch/Bambara \\
6 & Gmelina arborea & Gmelina \\
\hline
\end{tabular}

Source: Field Data Analysis, 2021.

Results from Fig. 1, reveals that, the reason for choice of species traded was due to demand $(43.33 \%)$, Durability (31.67\%) and Availability (15.00\%) from the study area. This agrees with the work of Awe et al. [3]. the work of Idumah and Awe [29] who, similarly, observed that the choice of wood species by furniture makers within Ibadan Metropolis was based, among other things, on the hardness (strength) and durability. Generally, demand and durability are the major reasons for choice of wood species as this is directly proportional to increase in population leading to more construction and industrial purposes to meet the demand.

Fig. 2 shows the fluctuations in species availability for trade in the study area shows that timber sellers agreed that there has been fluctuation and decline in the availability of the timber species traded within the last decades and various reasons were given for the fluctuations. Prominent among the reasons given was over-exploitation $(46.67 \%)$, followed by seasonality $(23.33 \%)$ among other reasons. This result agrees with the work of Awe et al., [3] who also recorded 54\% for over-exploitation as reason for fluctuations in species availability for Trade in Kogi.

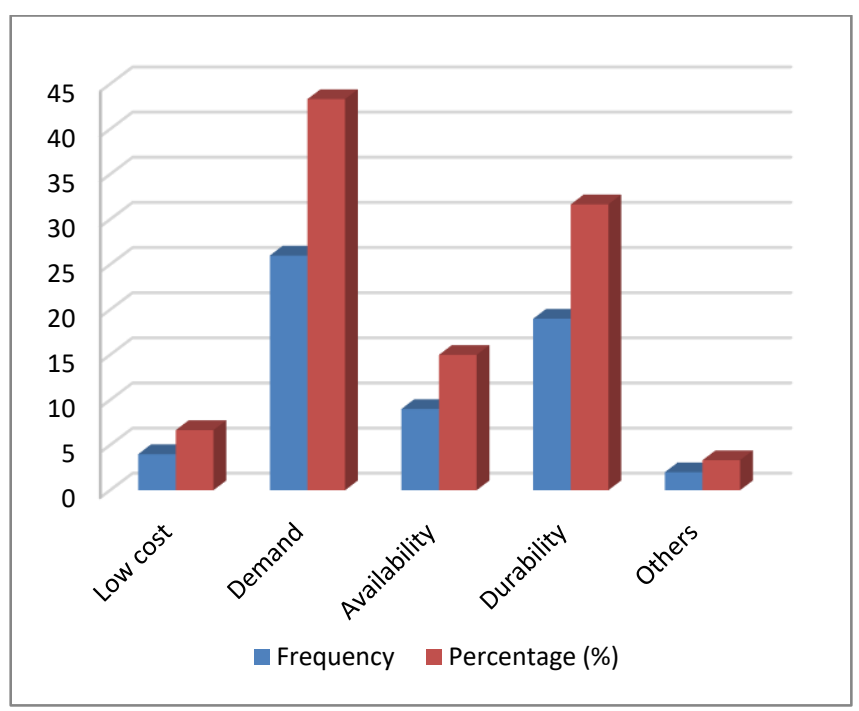

Fig. 1. Reason for choice of species traded.

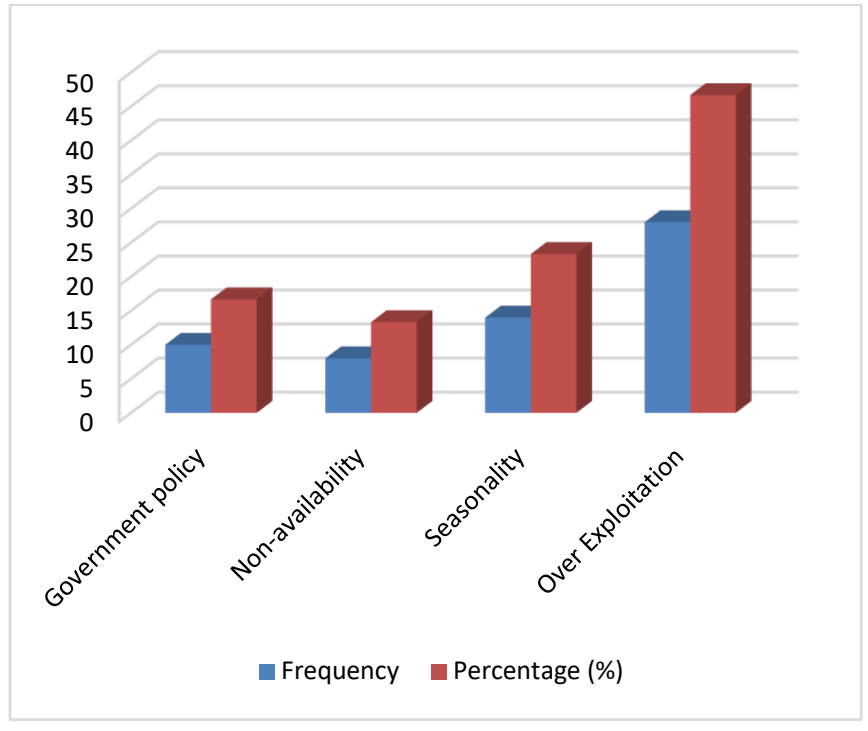

Fig. 2. Fluctuation in wood species availability for trade.

\section{E. Conservation Status of Plant Species in Taraba State}

Table VI shows that assessment of deforestation in the study area was high with $56.67 \%$ which shows decrease in availability of woody plant species. This has given rise to a high level of deforestation that showed clear evidence of desertion encroachment in the areas. Similar results were previously reported by Bunde [14], with high deforestation activities in Taraba State.

The results also, shows that $46.67 \%$ of the respondents said there is not any active afforestation programme by the locals except individuals who are making efforts to combat climate change in the area especially farmers who are concerned with protecting the environment. $96.67 \%$ said they have association from the community overseeing their activities yet no precaution seminar to guide all wood activities in the area. Wood loggers and dealers said, they usually pay revenue to the Government $(43.33 \%)$ and $36.67 \%$ said they usually pay revenue to security personnel who are meant to protect lives and properties in the area. This is an indication that government officials and security personnel are more concerned with exhortation from the wood dealers than taking care of the environment to preserve the nature's gift of the nation for sustainability.

The intensive logging practice has seriously damaged the composition and structure of woody plant species of the study area there by increasing the economic, social, and environmental problems such as desert encroachment, soil erosion, flood, drought, poverty, poor b soil quality, and health challenges. This means that the decline in tree cover affect aspects of daily life of the people in the study area [14].

This study is in line with the findings of Diaz [30] who reported that wood logging causes destruction of natural habitat of wild animals, destruction of vegetable species, fruit trees, and trees of medicinal importance as well as the disruption of essential microbial ecosystems. This condition leads to the loss of biodiversity, degrade the soil and it also encourages soil erosion as heavily deforested areas due to logging are left bare at the expense of runoffs during rainfall. The noise from chainsaw activities, felling of shade and foraging trees contributes to scaring the animals away. According to some informants in the study area, where most people are engaged in bee keeping, they have observed a high 
incidence of absconding of bees from their hives [20].

TABLE VI: Conservation Status of Plant Species in TARABa State

\begin{tabular}{|c|c|c|c|}
\hline $\mathrm{S} / \mathrm{N}$ & Variable & Frequency & Percentage $(\%)$ \\
\hline \multirow[t]{5}{*}{1} & $\begin{array}{l}\text { Assessment of } \\
\text { deforestation in the area }\end{array}$ & & \\
\hline & Very high & 21 & 35.00 \\
\hline & High & 34 & 56.67 \\
\hline & Low & 5 & 8.33 \\
\hline & Total & 60 & 100 \\
\hline \multirow[t]{5}{*}{2} & $\begin{array}{l}\text { Is there any afforestation } \\
\text { programme by the locals? }\end{array}$ & & \\
\hline & Yes & 13 & 21.67 \\
\hline & No & 28 & 46.67 \\
\hline & None of the above & 19 & 31.66 \\
\hline & Total & 60 & 100 \\
\hline \multirow[t]{4}{*}{3} & $\begin{array}{l}\text { Do you have any } \\
\text { association } \\
\text { your activities }\end{array}$ & & \\
\hline & Yes & 58 & 96.67 \\
\hline & No & 2 & 3.33 \\
\hline & Total & 60 & 100 \\
\hline \multirow[t]{5}{*}{4} & $\begin{array}{l}\text { Do you pay revenue, if yes } \\
\text { to who? }\end{array}$ & & \\
\hline & Government & 26 & 43.33 \\
\hline & Community & 12 & 20.00 \\
\hline & Security personnel & 22 & 36.67 \\
\hline & Total & 60 & 100 \\
\hline
\end{tabular}

Source: Field Data Analysis, 2021.

\section{CONCLUSIONS AND RECOMMENDATIONS}

A compendium of some under-utilised wood species has been produced from the study area, which may serve as alternative to the traded economic species for timber, poles, plywood, particle board, fibreboard production, carving, pulp and paper production and other industrial raw materials. Wood demand, durability and availability are the major reasons for choice of species traded while, over-exploitation and seasonality are the main reasons for fluctuations in species availability for trade. The intensive logging practice in the State has seriously damaged the composition and structure of woody plant species of the area there by, increasing the economic, social, and environmental problems such as desert encroachment, soil erosion, flood, drought, poverty, poor b soil quality, and health challenges. Species like Milicia excels, Ptericarpus erinaceus, Afzelia africana, Khaya senegalensis, Triplochiton scleroxylon, Terminalia superba among others are endangered in the State.

Wood demand, durability and availability are the major reasons for choice of species traded while, over-exploitation and seasonality are the main reasons for fluctuations in species availability for trade.

The produced compendium of some under-utilised wood species should be distributed widely so that producers, users, and marketers of wood products are aware of the promising species. Taraba State Government should, as a matter of urgency, review the forest policy to actually know the predicament against conservation and preservation of economic species that are facing extinction and forestry act be enacted to control the excesses of over-exploitation in various forests within the state. Special security forces/hunters, trained to work in this terrain, must be employed and deployed to counter terrorists, kidnappers, bandits, cannabis cultivators, rituals, and robbers in the forest reserves.

\section{ACKNOWLEDGEMENT}

The authors are grateful to the all-community heads of Ardo-Kola, Sarduna and Kurmi Local Government Areas of Taraba State who allowed the realization of this work in their premises.

\section{CONFLICT OF INTEREST}

The authors declare no conflict of interest.

\section{REFERENCES}

[1] J. T. B. Riki, O. A. Sotannde and A. O. Oluwadare, Selected Physical Properties and Microscopic Description of Ziziphus mauritiana Lam. Wood in Sudano-Sahelian Region of Nigeria, Asian Journal of Applied Sciences, 2019, vol. (7), pp. $2321-0893$

[2] J. A. Fuwape, Wood Utilisation from cradle to the grave. Federal University of Technology Akure, Inaugural Lecture series no. 25, 2000. pp. 1-33.

[3] F. Awe, R. I. Kolade and A. J. Ogunsola, Assessment of Timber Species Availability in Selected Sawmills and Timber Markets in Kogi State, Nigeria. Journal of Research in Forestry, Wildlife and Environment, 2019, vol. 11(3), pp. 239-245.

[4] A.O. Oluyege, Wood: A versatile material for natural development. Inaugural lecture Series 45, delivered at the Federal University of Technology, Akure 2007.

[5] Global Forest and Trade Network (GFTN). A sustainable future for the world's forests and for the people and economies that depend upon them. Panda Symbol WFF-World Wide Fund for Nature (formerly World Wildlife Fund) 2011.

[6] J. P. Yani, D. D. Peter, S. Vandi and B. B. Enoch, Harvesting, Trade and Impact of Logging Pterocarpus Erinaceous in Bali LGA of Taraba State, Nigeria, Journal of Agriculture and Environmental Sciences, 2020, vol. 9, no. 2, pp. 77-85.

[7] Taraba State Investment and Property Limited. Taraba, Investments Report 2014, Jalingo, 2014, pp. 1-5.

[8] J. Russell-Smith and A. C. Edwards, Price of Simplifying the Savanna: The trajectory of fire-sensitive vegetation mosaics innorthern Australia, Journal of Biogeography, 2012, vol. (39), pp. 1303-1317.

[9] D.K. Das and M. Mohiuddin, Anatomical studies of forty-two lesser used or unused wood species of Bangladesh, 1999 Bull, no. 15 (Wood Anatomy Series). Bangladesh Forest Research Institute, Chittagong.

[10] M. Barany, A. L. Hammett and P. Araman, Lesser used species of Bolivia and their relevance to sustainable forest management, 2003 Forestry Products Journal, vol. 53(7/8), pp. 28-33.

[11] International Tropical Timber Organization. Status of Tropical Forest Management. ITTO Technical Series, No. 24, 2010. pp 32.

[12] Taraba Youth Progressive Association of Nigeria (TYPA), 2009. Report on small scale environmental studies in Taraba state.

[13] D.O. Emeka and B. Abbas, The geography of Taraba State, Nigeria Australia: 2011, LAP LAMBERT academic publishing LTD.

[14] M. B. Bunde, Threats and conservation status of woody plant species in different ecological zones of Taraba State, Nigeria, 2018. Advances in Plants and Agriculture Research. 2018, vol. (8)6, pp. 443-447.

[15] O. Ajayi and R. O. Ojutiku, Economic evaluation of artisan fishermen among rural folks in Katcha Local Government Area of Niger State, Nigeria. Journal of Agricultural Research and Policies, 2008, vol. 3(1), pp. 102-106.

[16] A. A. Aiyeloja, A. T. Oladele. and C. S. Ozoemena, Socio-Economic Analysis of Wood Furniture Production In Rivers State, Nigeria, Journal of Tropical Forestry Resources, 2014, vol. 30(2014), pp. 126135 .

[17] K.M. Ogunjobi, A. T. Shittu, O. F. Gakenou, O. C. Ashade and A. C. Adetogun, Preference of Wood Species used for Furniture making in Abeokuta, Ogun State, Nigeria, Journal of Forest Science and Environment, 2018, vol. 3 (1), pp. 30-36.

[18] C. Manfre and D. Rubin, Integrating Gender into Forestry Research: A Guide for CIFOR Scientists and Programme Administrators. Center for International Forest Research,Bogor, Indonesia, p. 121.2012.

[19] International Labour Organisation (ILO). ASEAN in transformation: Perspectives of enterprises and students on future work (Geneva, 2016)

[20] S. David, “Agile Innovation.” Bain. December 26, 2018. Accessed May 13, 2019

[21] R.A. Omolehin, T. O. Ogunfiditimi and O. B. Adeniji, Factors Influencing Adoption of Chemical Pest Control in Cowpea Production 
among Rural Farmers in Makarfi Local Government Area of Kaduna State, Nigeria, Journal of Agricultural Extension, vol. 10, 5, 2007.

[22] H. J. Holzer, The Determinants of Employee Productivity and Earnings: Some New Evidence, National Bureau of Economic Research Cambridge, MA, Working Paper No. 2782, 1988.

[23] S. Harper, Workplace stress and the student learning experience, Qual. Assur. Educ., 2006, 14(2), pp. 167-178.

[24] T. O. Khider, S. Omer and O. Taha, Alkaline Pulping of Typha domingensis Stems from Sudan. World Applied Sciences Journal 2011, vol. 16 (3), pp. 331-336.

[25] S.Y. Zhang, Wood Quality Attributes and Their Impacts on Woood Utilization. S.Y. Quebec City, Canada FAO Publication. 0674-B1.

[26] B. R. Soltis, Mechanical Properties of Wood and Wood Composites, Journal of Structural Engineering, 1994, vol. 115, pp. 77-82.

[27] K. Poku, W. Qinglin and R. Vlosky, Wood properties and their variations within the tree stem of lesser-used species of tropical hardwood from Ghana, Wood Fiber Science, 2001, vol. 33, pp. 284 291.

[28] O.O. Famuyide, O. Adebayo, A.V. Odebode, F. Awe, O.B. Ojo and D. Ojo, Timber Species Availability and Variation in Ibadan and Oyo Timber Markets over the last Forty Years, Elixir Journal of Biodiversity, 2012, vol. 49, pp. 10131-10136.

[29] F.O. Idumah and F. Awe, Assessment of the Types of Wood used in the Furniture Making Industry in Ibadan Metropolis, Journal of Sustainable Environmental Management, vol. 3, pp. 117-121, 2011.

[30] S. Diaz, Biodiversity loss threatens human well-being. Biology. 2006 vol. 4(8), pp. 277. 